\title{
Morphological Skills: A Key Parameter in Dealing with Written Expression and Spelling in Specific Learning Disabilities
}

\author{
Garyfalia Charitaki', Spyridon-Georgios Soulis², Sotiria Tzivinikou ${ }^{3}$, Eleni Peklari ${ }^{4}$ \\ ${ }^{1}$ Hellenic Open University, Patras, Greece \\ ${ }^{2}$ Department of Primary Education, University of Ioannina, Ioannina, Greece \\ ${ }^{3}$ Department of Special Education, University of Thessaly, Volos, Greece \\ ${ }^{4}$ Cass School of Education, AKMI Metropolitan College in Collaboration with University of East London, Athens, Greece \\ Email: charitaki.garyfalia@ac.eap.gr, ssoulis@uoi.gr, sotitzivi@uth.gr, epeklari@amcstudent.edu.gr
}

How to cite this paper: Charitaki, G. Soulis, S.-G., Tzivinikou, S., \& Peklari, E. (2018). Morphological Skills: A Key Parameter in Dealing with Written Expression and Spelling in Specific Learning Disabilities. Creative Education, 9, 879-900. https://doi.org/10.4236/ce.2018.96065

Received: March 30, 2018

Accepted: May 13, 2018

Published: May 16, 2018

Copyright $\odot 2018$ by authors and Scientific Research Publishing Inc. This work is licensed under the Creative Commons Attribution International License (CC BY 4.0).

http://creativecommons.org/licenses/by/4.0/

\section{Open Access}

\begin{abstract}
Many researchers recently focus on Specific Learning Disabilities due to the significant percentage of students recently diagnosed with SLD (American Psychiatric Association, 2013). This study basically aims in investigating the effect of Morphological Skills in written expression and spelling through an intervention project. The sample of the research consisted of 7 participants who coped with significant difficulty in written speech and orthography. Their chronological age was between 10;01 (y;m) and 12;08 $(\mathrm{M}=11.07, \mathrm{SD}=$ 0.05). The project lasted for a 10-week period (March 2017 - May 2017). Semi-structured interviews with participants' parents, teachers and special educators were also conducted in order to increase the credibility and validity of the results. A screening test was also designed in order to evaluate the qualitative elements of the participants' progress with accuracy. The results from Friedman non-parametric statistical test showed statistically significant elimination of errors in general $\left(\chi^{2} \mathrm{~F}(1)=7.000, p=0.008<0.05\right)$, in nouns $\left(\chi^{2} \mathrm{~F}(1)=7.000, p=0.008<0.05\right)$, in verbs $\left(\chi^{2} \mathrm{~F}(1)=7.000, p=0.008<0.05\right)$ and in adjectives $\left(\chi^{2} \mathrm{~F}(1)=4.000, p=0.046<0.05\right)$.
\end{abstract}

\section{Keywords}

Specific Learning Disabilities, Written Speech, Spelling, Grammar

\section{Introduction}

Over the last years, there has been a remarkably increasing occurrence of SLD in primary and secondary school population respectively. Actually, researchers 
converge to the claim that grammar in children with specific language impairment is acquired in a different way compared to typically developing children (Conti-Ramsden, Ullman, \& Lum, 2015). Another interesting field is that SLD with impairment in written expression can sometimes coexist with or without disturbances in reading (Snowling, 2000). It is also related to an unusually persistent difficulty in acquiring basic attainments in written expression and spelling. There is also a difficulty not only in matching an acoustic stimulus to written speech, but also in applying grammatical rules in writing words, proposals and paragraphs as well (Gena, 2004). The literacy skills are closely linked. The development of one affects the development of the other and determines the overall expression and cognitive development in children with intellectual disability (Georgala \& Charitaki, 2016). Nevertheless, it is a prerequisite to exclude children with intellectual disability from the population (Vogindroukas \& Grigoriadou, 2000). Individual learning, achievement and progress constitute the focal point of intervention programmes for students with special educational needs. Thus, the instruction in special education classrooms and resource rooms in inclusive schools has to be specific, directed and individualized (Tzivinikou \& Papoutsaki, 2016). The main objective of this research is to investigate the effectiveness of an intervention programme based on understanding and applying grammatical rules to eliminate mistakes in written expression.

\section{Theoretical Framework}

Many researchers highlight the importance of researching the effectiveness of alternative educational approaches in SLD. Theoretical positions and research data are related to specific issues in SLD, such as conceptual content, causal entity, clinical picture and strategic interventions emphasizing the complexity of the phenomenon (Alevizou, 2002). SLD are directly correlated to low academic attainment-performance and school failure. School failure is determined by the student's inability to perform according to expected levels of learning and behavior as defined through Curriculum and Developmental Trajectories. Low performance is specifically identified in cognitive areas of both reading and mathematical attainments, which share common risk factors associated with attention problems (processing speed, temporal processing, and working memory) (Moll, Göbel, Gooch, Landerl, \& Snowling, 2016). School failure is quite often highly correlated to students' emotional development and averseness to school with an immediate effect on teachers and parents as well (Andrianopoulou, 2014).

Moreover SLD remain so far a controversial and complicated area in terms of delimitation, criteria, assessment and intervention, which must be adjusted to the needs of each child (Stergiou, 2009). School counseling services in public schools, could not only support students, but also train parents and teachers. However, in Greece, very few school counselors are responsible for the supervision of numerous schools-a reality which creates a further difficulty in dealing with SLD. Gillespie \& Graham (2014) made an effort to investigate the effec- 
tiveness of writing interventions on the quality of writing produced considering SLD. They clearly stated the impact of interventions based on strategy instruction, dictation, procedural facilitation, prewriting, goal setting, and process writing to students' with SLD writing quality. Bouwer, Koster, \& van den Bergh (2018) also stated a clear improvement to upper-elementary students' written language skills through the implementation of a strategy-focused instructional program on the writing quality of upper elementary students in the Netherlands.

According to Ehri (2014) orthographic mapping involves the formation of letter-sound connections to bond the spellings, pronunciations, and meanings of specific words in memory. It is related to the way children learn to read words through optical stimulus and spell words. It has been proved by efforts which have been made that pronouncing novel words aloud can help students with SLD develop their linguistic skills. Low Performance in the writing skills of children's with SLD worried many researchers. More specifically, computer scientists and educational researchers who made efforts to prove that computerized learning activities tend to be effective for children with SLD in learning reading and writing skills (Tanimoto, Thompson, Berninger, Nagy, \& Abbott, 2015). Berninger, Nagy, Tanimoto, Thompson, \& Abbott (2015), have also proved that the use of iPad for interventions in children with SLD can be effective in creating a functional writing system.

However, research data on SLD are still eliminated in terms of investigating the effect of grammatical rules in written expression and spelling through an intervention project. According to a theory (Rice \& Wexler, 1996), children with SLD are not able to grasp the grammatical principle of inflection, so as to determine linguistic relationships such as subject-verb agreement and grammatical case assignment. As a result, there is a failure to proceed from an early "optional infinitive" to an acquisition stage, during which the application of inflectional rules is not obligatory. In line to this view, errors derive from a nescience that morphological marking is a prerequisite. Another controversial theory (Pinker, 1989; Gopnik \& Crago, 1991; Gopnik, 1997) poses the focal point of morphological deficit to the inability to learn inflectional rules. Rote learning of individual inflected words seems to be the basic outcome of their inability to formulate rules. On this account, the basic assertion is that language involves rules. This rule-forming capacity can be congenitally impaired in SLD (Joanisse \& Seidenberg, 1998). Sanders, Berninger \& Abbott (2018) evaluated predictors of reading and writing achievement in children with SLD and concluded that orthographic word-form coding uniquely predicted every measure. Berninger \& O'Malley May (2011) highlighted the importance of differences among individuals with SLD in evaluating instruction and suggested that teaching may change epigenetic gene expression.

This study attempts to shed light on this issue by implementing an intervention project based on the grammatical rules for spelling of nouns, adjectives and verbs. More specifically, there is an intention to investigate the effect of Mor- 
phological Skills in written expression and spelling.

\section{Methodology}

\subsection{Research Design}

The research is an intervention project designed in order to improve the spelling of young children through the understanding and application of grammatical rules. Primary school students were enrolled to the programme, so as to examine the effect of the grammatical rules in improving participant's spelling skill. At the beginning, the students were evaluated in relation to their levels of spelling and dictation. The project lasted for 10 weeks (March 2017 - May 2017). There were implemented 2 sessions, which lasted for 30 minutes, in a weekly basis. Afterwards there was a reassessment of the students' abilities in spelling and dictation in order to check the improvement in students' skills. Semi-structured interviews were also taken from special educators in order to increase the reliability and validity of the study. The data collected from the interviews provided us with sufficient data, which enabled us to implement methodological triangulation.

\subsection{Research Participants}

The participants in this study were students $(\mathrm{N}=7)$ diagnosed with Specific Learning Disabilities in written expression enrolled in typical primary schools. All students attended the resource classrooms 3 times a week. Their chronological age was between 10;01 $(\mathrm{y} ; \mathrm{m})$ and $12 ; 08(\mathrm{M}=11.07, \mathrm{SD}=0.05)$. According to educators and parents, the students had severe difficulties not only in recognizing and writing the right consonants during dictation but also in spelling, generally. All students had one younger sibling, a hobby (swimming, football, ballet), copped with housework, had a good level of independent living and could deal with money frequently. There were 3 children who had no friends and were alone for the larger time of day in school.

\subsection{Data Collection Instruments/Research Tools}

Generally speaking, written expression in SLD still remains a demanding domain of Special Education which requires a targeted and well-designed intervention programme. The significance of this intervention project is related to the fact that it can provide intervention tools to special educators. The research tools (pre-test, post-test, semi-structured interviews, worksheets), which were used in order to have an effectiveness check for the parameter of Grammatical Rules in written expression, are listed in detail below.

\subsubsection{Pre-Test/Post-Test}

In cases where the provision of a standardized criterion is not feasible by a directly involved educator or psychologist, the next move is the construction and delivery of an informal screening test for assessing learner's learning difficulties 
by the educator or the psychologist himself. Although these screening tests are not systematically applied, as they are not standardized in the wider population, they can give us enough reliable data on students' cognitive abilities, provided that their construction is based on scientifically substantiated evidence but also on their application, to be done with method, accuracy and accountability by the educator involved. The informal screening tests for pupils' cognitive abilities should include a series of individual cognitive activities that illustrate both the type and degree of difficulty the student presents.

With regard to obtain the validity of data collected for the effectiveness of the intervention, the same screening test (pre-test/post-test) was administered at the beginning ( $1^{\text {st }}$ week) and in the end of this intervention (10th week). The time interval was chosen to be defined at a 10 week period, because it is not only sufficient to avoid the emergence of memory effect for the screening test (Brown, Irving, \& Keegan, 2008), but also to the effectiveness of the intervention. The screening test included 4 tasks, which were chosen in order to evaluate the level of the difficulty in written expression and especially in spelling skills (Appendix A).

\subsubsection{Interview}

A semi-structured interview was taken from one of each child's parents in order to outline each child's profile (age, gender, class, siblings, extracurricular activities, coping with housework, independent living, dealing with money and having friends). A semi-structured interview was also taken from each child's educator in order to be provided with sufficient data to implement methodological triangulation for the effectiveness check for the parameter of Grammatical Rules in written expression (spelling nouns, adjectives and verbs) (Appendix B).

\subsubsection{Worksheets}

For the implementation of the intervention project activities which utilize the grammatical rules for the teaching of spelling of nouns, adjectives and verbs, were used. All the proposed activities have been taken from the bibliography (Dimitriadou, 2014). Below, indicative worksheets from each category: nouns (Appendix C), adjectives (Appendix D), verbs (Appendix E) can be shown.

\section{Intervention}

During $1^{\text {st }}$ week, the pre-test which included 5 tasks was administered. The main objective of this test was to identify the specific difficulties that each student faces with regard to the correct writing of nouns, adjectives and verbs through unknown texts. There were systematic errors in nouns, adjectives and verbs for all students of the sample. At the second session of the first week errors were discussed, students were reminded of the grammatical rules and a short discussion for the objectives of the intervention programme took place.

From the $2^{\text {nd }}$ to $9^{\text {th }}$ week, the students worked separately with their tutor, as the one-to-one teaching approach was used. For the entire programme 50 
worksheets were used, which included; games, tracing and concentration exercises.

During the $10^{\text {th }}$ week, the post-test was administered, which for methodological purposes was the same as the pre-test (Appendix A).

\section{Results}

There was a clear differentiation in all children's writing attainment in nouns, adjectives and verbs. For the Hypothesis checking the Friedman non-parametric statistical test was used. As it can be shown in Table $1 \&$ Table 2, all students participated in the sample eliminated their errors in general. The Results from Friedman non-parametric statistical (Table 3 ) test showed statistically significant elimination of errors in general $\left(\chi^{2} \mathrm{~F}(1)=7.000, p=0.008<0.05\right)$, in nouns $\left(\chi^{2} \mathrm{~F}(1)=7.000, p=0.008<0.05\right)$, in verbs $\left(\chi^{2} \mathrm{~F}(1)=7.000, p=0.008<0.05\right)$ and in adjectives $\left(\chi^{2} \mathrm{~F}(1)=4.000, p=0.046<0.05\right)$ Table 3.

Educators' perceptions also indicate a differentiation in students' attainments in writing. As it can be shown in Table 4, for the majority of students they Agree

Table 1. Comparative results for the number of errors and number of errors in nouns from the pre/post-test administration.

\begin{tabular}{cccc}
\hline \multicolumn{2}{c}{ Number of Errors } & \multicolumn{2}{c}{ Errors in Nouns } \\
\hline Pre-Intervention & Post-Intervention & Pre-Intervention & Post-Intervention \\
\hline 37 & 20 & 9 & 6 \\
46 & 24 & 14 & 7 \\
40 & 27 & 12 & 9 \\
36 & 21 & 11 & 5 \\
33 & 23 & 9 & 7 \\
26 & 15 & 7 & 5 \\
24 & 15 & 8 & 6
\end{tabular}

Table 2. Comparative results for the number of errors in verbs and adjectives from the pre/post-test administration.

\begin{tabular}{cccc}
\hline \multicolumn{2}{c}{ Errors in Verbs } & \multicolumn{2}{c}{ Errors in Adjectives } \\
\hline Pre-Intervention & Post-Intervention & Pre-Intervention & Post-Intervention \\
\hline 20 & 10 & 8 & 4 \\
25 & 10 & 7 & 7 \\
22 & 12 & 6 & 6 \\
14 & 7 & 11 & 9 \\
19 & 12 & 5 & 3 \\
12 & 7 & 7 & 6 \\
10 & 3 & 6 & 3
\end{tabular}


Table 3. Friedman test for the number of errors in nouns, verbs and adjectives from the pre/post-test administration.

\begin{tabular}{ccccc}
\hline & \multicolumn{3}{c}{ Friedman Test } \\
\cline { 2 - 5 } & $\mathrm{N}$ & Chi-Square & $\mathrm{df}$ & Asymp. Sig. \\
\hline Errors in Adjectives & 7 & 4.000 & 1 & 0.046 \\
Errors in Verbs & 7 & 7.000 & 1 & 0.008 \\
Errors in Nouns & 7 & 7.000 & 1 & 0.008 \\
Number of Errors & 7 & 7.000 & 1 & 0.008 \\
\hline
\end{tabular}

Table 4. Results from the educators' semi-structured interview.

\begin{tabular}{lccc}
\hline & Mean (m) $\begin{array}{c}\text { Standard } \\
\text { Deviation (sd) }\end{array}$ & Min & Max \\
\hline $\begin{array}{l}\text { There is an elimination in student's errors in written } \\
\text { expression in general. }\end{array}$ & 4 & 0.82 & 3 \\
$\begin{array}{l}\text { There is an elimination in student's errors in written } \\
\text { expression in nouns. }\end{array}$ & 3.71 & 0.49 & 3 \\
$\begin{array}{l}\text { There is an elimination in student's errors in written } \\
\text { expression in verbs. }\end{array}$ & 4.3 & 0.29 & 5 \\
$\begin{array}{l}\text { There is an elimination in student's errors in written } \\
\text { expression in adjectives. }\end{array}$ & 4.4 & 0.53 & 4 \\
\hline
\end{tabular}

or Strongly Agree that there an elimination in writing errors in general $(\mathrm{m}=4$, $\mathrm{sd}=0.82)$, in nouns $(\mathrm{m}=3.71$, sd $=0.49)$, in verbs $(\mathrm{m}=4.3$, sd $=0.29)$ and in adjectives $(\mathrm{m}=4.4, \mathrm{sd}=0.53)$. They all gave examples from students' daily task of dictation. The most important, that they explicitly mentioned, was the primary recognition and application of grammatical rules. Also, a clear improvement was remarked in accentuation of nouns, adjectives and verbs.

According to the findings of the implementation of intervention programme in students who were diagnosed with SLD in written expression it can be said that Grammar can be a key parameter in order to cope with such difficulties.

\section{Discussion}

This research attempt could be placed among the efforts that have been made in order to examine the phenomenon of persistent writing difficulties in children with SLD. The hypothesis testing showed that the grammar based intervention programme could be effective for students diagnosed with SLD. The influence of the grammatical rules in dealing with difficulties in spelling was evident in the case of students with SLD. Impairments in the child's innate knowledge of grammar seems to be highly correlated with the inability to develop typical language skills (Joanisse \& Seidenberg, 1998). Sanders, Berninger \& Abbott (2018) evaluated predictors of reading and writing achievement in children with SLD and concluded that orthographic word-form coding uniquely predicted every measure. 
Psycholinguistic theories emphasize that grammar constitutes a distinct component which can eliminate emergence of errors in grammatical phenomena with the use of appropriate treatment (Ullman et al., 1997). According to Ehri (2014) optical stimulus that it is provided can closely be related to the way children learn to read words through and spell words. Grammar can provide such stimulus and as a result it can be effective. Rice \& Wexler (1996) claim that children with SLD are not able to gasp the grammatical principle of inflection, so as to determine linguistic relationships such as subject-verb agreement and grammatical case assignment. As a result, there is a failure to proceed from an early "optional infinitive" to an acquisition stage, during which the application of inflectional rules is not obligatory. In line to this view, errors derive from a nescience that morphological marking is prerequisite and consequently, a grammar based intervention can be a key parameter in promoting written speech.

Dienes \& Berry (1997), claim that there are two different types of learning the explicit and the implicit, depending on the concept of cognizance the degree of accessibility of the acquired information. So explicit learning could ideally be derived when conscious knowledge is accessible (Shanks \& John, 1994), through appropriate intervention programmes. Moreover, individual learning, achievement and progress constitute the focal point of intervention programmes for students with special educational needs. Berninger \& O’Malley May (2011) highlighted the importance of differences among individuals with SLD in evaluating instruction and suggested that teaching may change epigenetic gene expression. Thus, the effectiveness of the proposed intervention is closely related to the fact that instruction in special education classrooms and resource rooms in inclusive schools has to be specific, directed and individualized (Tzivinikou \& Papoutsaki, 2016).

\section{Educational Implications}

Children with SLD seem to acquire an incomplete understanding and application of grammatical rules in the written expression, resulting in spelling errors. Graham \& Hebert (2010) have shown that writing instruction is closely related to the reading improvement and as a result to overall literacy skills improvement. The current results show that the use of contexts enriched with a variety of visual stimuli can support effective interventions. Grammatical rules can be applied through a wide range of activities including tasks and games.

\section{Limitations \& Future Suggestions}

The research design included mixed methodological approach, which enabled to triangulate. Though, there were various limitations. One limitation is related to the limited size of the sample which consists of 7 students. Additional research is needed to be conducted with a larger sample of participants. Given the insufficient research data in the field of SLD in Greece, the conclusions drawn from this study are considered important and are expected to enrich the scientific re- 
search and trigger new studies. The research data can be considered for a future enrichment through further pilot research with the exploitation of information and through quality research methods. Valuable material and essential feedback can be derived from interviews with special educators, thus achieving a thorough collection of qualitative data.

An additional future perspective of research may include the assessment of the intervention programme through the use of ICT, more specifically, a study on the effect of the use of iPad to intervene in children with SLD in creating a functional writing system and eliminating spelling errors.

\section{Acknowledgements}

This study would not have been possible without the contribution of numerous people. We would like to thank the educational staff who took part in the research. We are also grateful to the parents for the willingness to allow their children to participate in the study.

\section{References}

Alevizou, E. (2002). Special Learning Difficulties of Child and Adolescent. The Case of Dyslexia. Counseling-Supporting Programs, Bachelor Thesis, Kalamata: Technological Educational Institution.

American Psychiatric Association (2013). Diagnostic and Statistical Manual of Mental Disorders $\left(D S M-5^{\circledR}\right)$. Washington DC: American Psychiatric Association Publishing.

Andrianopoulou, A. (2014). Specific Learning Difficulties, Types and Therapeutic Intervention. Bachelor Thesis, Kalamata: Higher Technological Educational Institute.

Berninger, V. W., \& O’Malley May, M. (2011). Evidence-Based Diagnosis and Treatment for Specific Learning Disabilities Involving Impairments in Written and/or Oral Language. Journal of Learning Disabilities, 44, 167-183. https://doi.org/10.1177/0022219410391189

Berninger, V. W., Nagy, W., Tanimoto, S., Thompson, R., \& Abbott, R. D. (2015). Computer Instruction in Handwriting, Spelling, and Composing for Students with Specific Learning Disabilities in Grades 4-9. Computers \& Education, 81, 154-168. https://doi.org/10.1016/j.compedu.2014.10.005

Bouwer, R., Koster, M., \& van den Bergh, H. (2018). Effects of a Strategy-Focused Instructional Program on the Writing Quality of Upper Elementary Students in the Netherlands. Journal of Educational Psychology, 110, 58-71.

https://doi.org/10.1037/edu0000206

Brown, G., Irving, E., \& Keegan, P. (2008). An Introduction to Educational Assessment, Measurement and Evaluation. Auckland, NZ: Pearson Education.

Conti-Ramsden, G., Ullman, M. T., \& Lum, J. A. (2015). The Relation between Receptive Grammar and Procedural, Declarative, and Working Memory in Specific Language Impairment. Frontiers in Psychology, 6, 1090.

Dienes, Z., \& Berry, D. (1997). Implicit Learning: Below the Subjective Threshold. Psychonomic Bulletin \& Review, 4, 3-23. https://doi.org/10.3758/BF03210769

Dimitriadou, I. (2014). Grammar with Another Optics. Worksheets for Children with Learning Difficulties. Athens: ikid Bookstore.

Ehri, L. C. (2014). Orthographic Mapping in the Acquisition of Sight Word Reading, 
Spelling Memory, and Vocabulary Learning. Scientific Studies of Reading, 18, 5-21. https://doi.org/10.1080/10888438.2013.819356

Gena, A. (2004). Children with Mild Learning and Behavioral Disorders: Prerequisites and Teaching Methodology for Their General Classroom Education. In A. Kalantzi-Azizi, \& M. Zaphiropoulou (Ed.), The School Adaptation (pp. 194-221). Athens: Ellinika Grammata.

Georgala, M. G., \& Charitaki, G. (2016). Investigating Language Attainments in Students



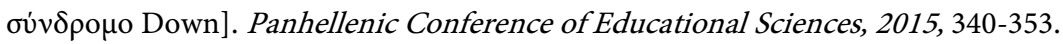
https://doi.org/10.12681/edusc.188

Gillespie, A., \& Graham, S. (2014). A Meta-Analysis of Writing Interventions for Students with Learning Disabilities. Exceptional Children, 80, 454-473.

https://doi.org/10.1177/0014402914527238

Gopnik, M. (1997). Language Deficits and Genetic Factors. Trends in Cognitive Sciences, 1, 5-9.

Gopnik, M., \& Crago, M. (1991). Familial Aggregation of a Developmental Language Disorder. Cognition, 39, 1-50.

Graham, S., \& Hebert, M. A. (2010). Writing to Read: Evidence for How Writing Can Improve Reading. A Carnegie Corporation Time to Act Report. Washington DC: Alliance for Excellent Education.

Joanisse, M. F., \& Seidenberg, M. S. (1998). Specific Language Impairment: A Deficit in Grammar or Processing? Trends in Cognitive Sciences, 2, 240-247.

https://doi.org/10.1016/S1364-6613(98)01186-3

Moll, K., Göbel, S. M., Gooch, D., Landerl, K., \& Snowling, M. J. (2016). Cognitive Risk Factors for Specific Learning Disorder: Processing Speed, Temporal Processing, and Working Memory. Journal of Learning Disabilities, 49, 272-281.

https://doi.org/10.1177/0022219414547221

Pinker, S. (1989). The Language Instinct. New York: Harper Collins.

Rice, M. L., \& Wexler, K. (1996). A Phenotype of Specific Language Impairment: Extended Optional Infinitives. In M. L. Rice (Ed.), Towards a Genetics of Language (pp. 215-237). Mahwah, NJ: Lawrence Erlbaum.

Sanders, E. A., Berninger, V. W., \& Abbott, R. D. (2018). Sequential Prediction of Literacy Achievement for Specific Learning Disabilities Contrasting in Impaired Levels of Language in Grades 4 to 9. Journal of Learning Disabilities, 51, 137-157. https://doi.org/10.1177/0022219417691048

Shanks, D. R., \& John, M. F. (1994). Characteristics of Dissociable Human Learning Systems. Behavioral and Brain Sciences, 17, 367-395.

https://doi.org/10.1017/S0140525X00035032

Snowling, M. (2000). Dyslexia. Oxford: Blackwell.

Stergiou, E. (2009). Specific Learning Difficulties: Emotional Components and Family Environment. Bachelor Thesis, Ioannina: Technological Educational Institution of Epirus.

Tanimoto, S., Thompson, R., Berninger, V. W., Nagy, W., \& Abbott, R. D. (2015). Computerized Writing and Reading Instruction for Students in Grades 4-9 with Specific Learning Disabilities Affecting Written Language. Journal of Computer Assisted Learning, 31, 671-689. https://doi.org/10.1111/jcal.12110

Tzivinikou, S., \& Papoutsaki, K. (2016). Studying Teaching Methods, Strategies and Best Practices for Young Children with Special Educational Needs. Early Child Develop- 
ment and Care, 186, 971-980. https://doi.org/10.1080/03004430.2015.1071101

Ullman, M. T., Corkin, S., Coppola, M., Hickok, G., Growdon, J. H., Koroshetz, W. J., \& Pinker, S. (1997). A Neural Dissociation within Language: Evidence That the Mental Dictionary Is Part of Declarative Memory, and That Grammatical Rules Are Processed by the Procedural System. Journal of Cognitive Neuroscience, 9, 266-276. https://doi.org/10.1162/jocn.1997.9.2.266



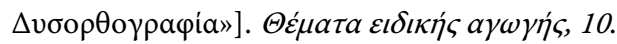




\section{Appendix A. Pre-Test/Post-Test}

\section{Pre-Test/Post-Test}

\section{Student's Name:}

Date:

\section{Dictation}

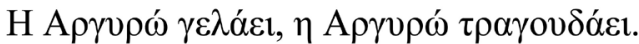

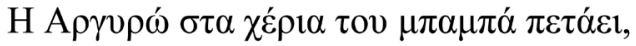

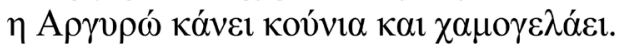

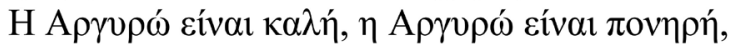

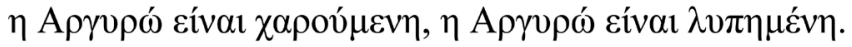

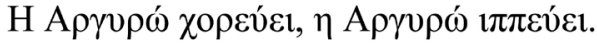

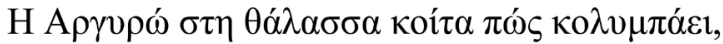

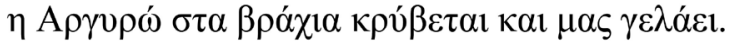

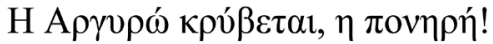

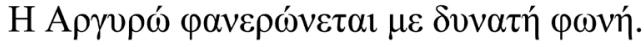

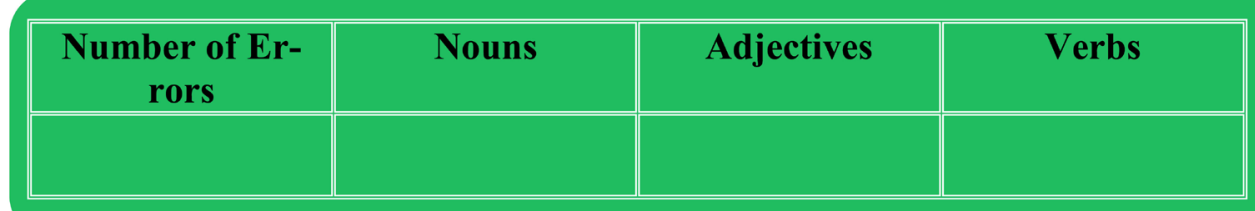


2. Fill in the endings.
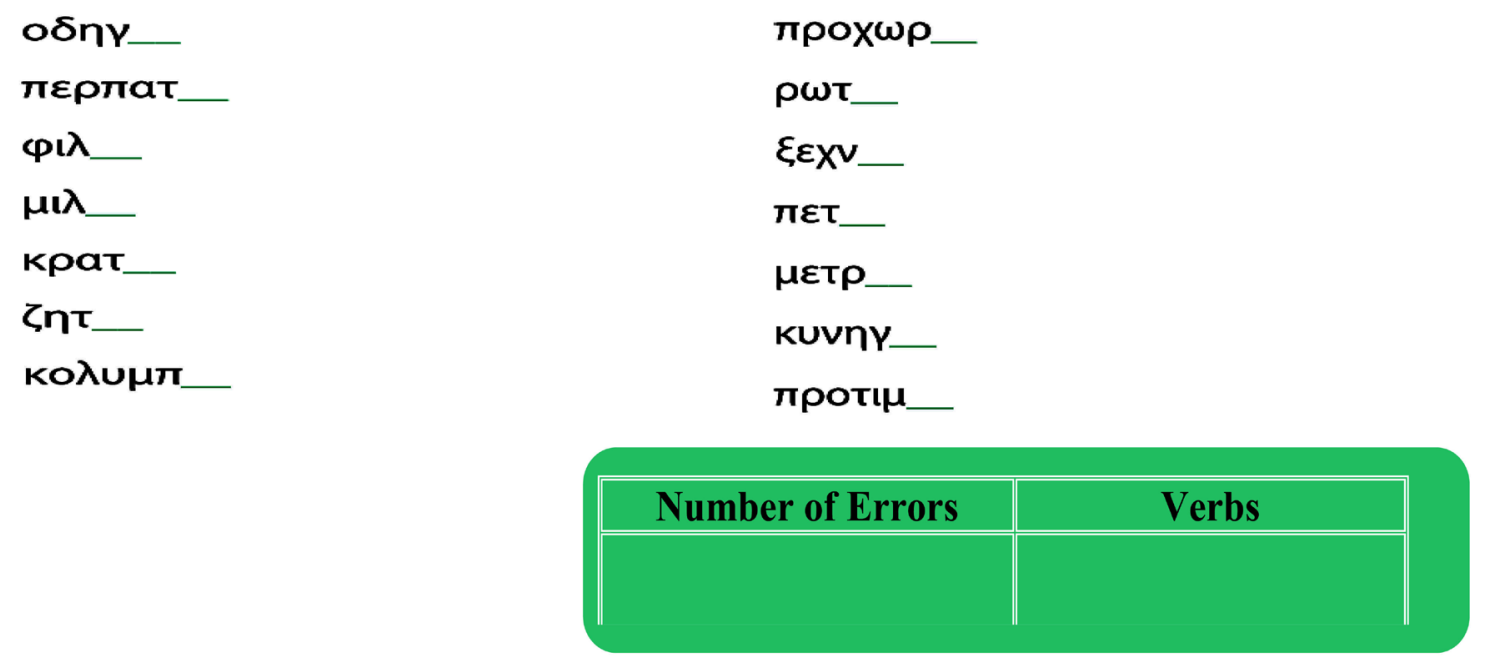

3. Fill in the endings.

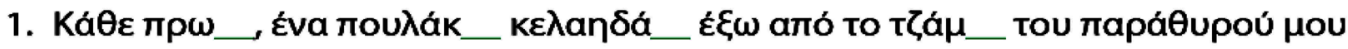

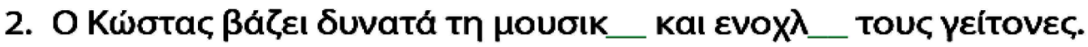

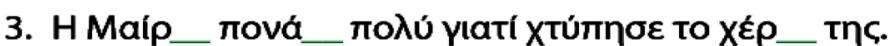

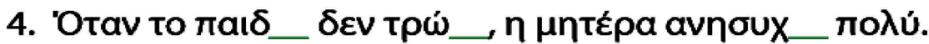

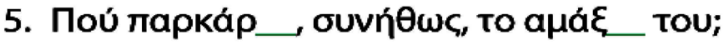

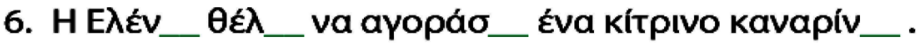

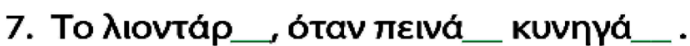

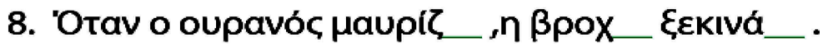

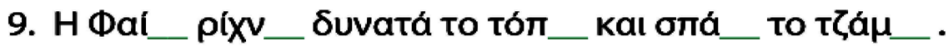

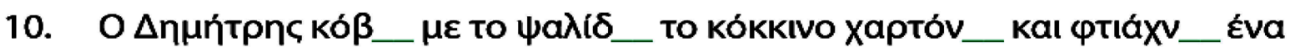

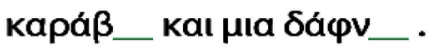

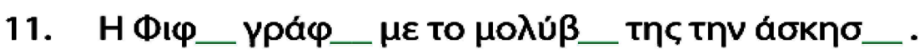


4. Fill in the endings.

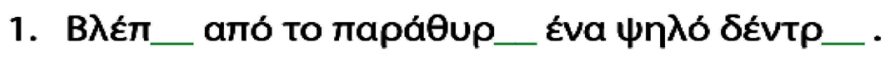



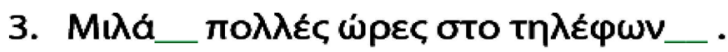

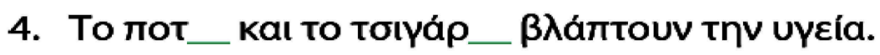

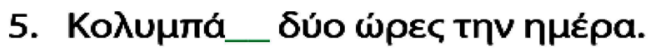

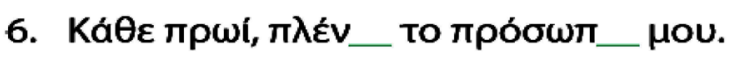

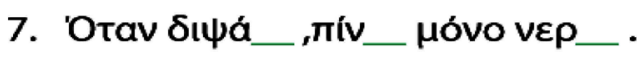

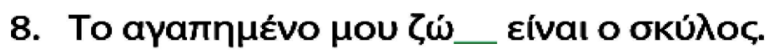

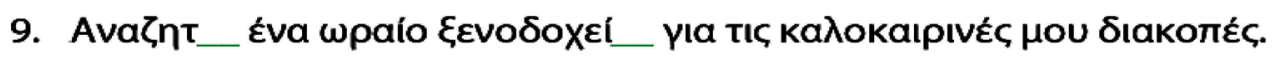

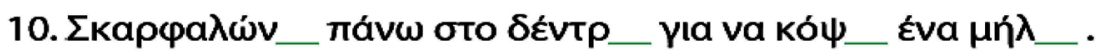

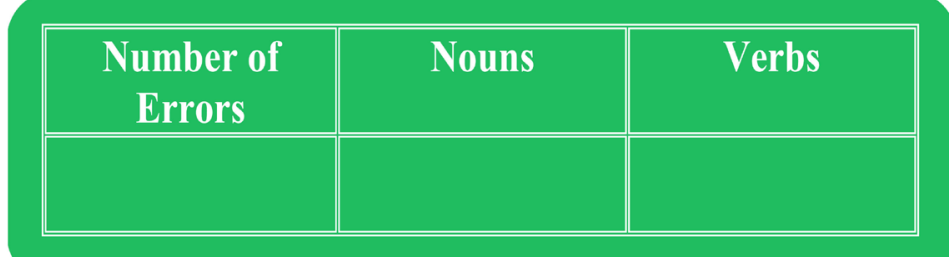




\section{Appendix B. Semi-Structured Interview Guide (Educators)}

You are asked to depict the degree of your agreement with the following sentences by taking into consideration your student's Attainments over the last 10 weeks.

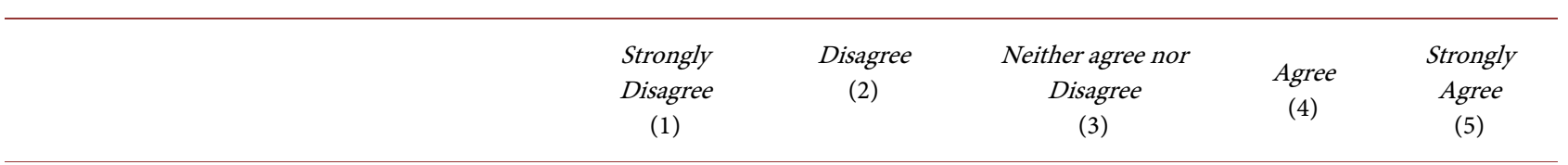

1) There is an elimination in student's errors in written expression in general.

Could it be easy to give me an example?

2) There is an elimination in student's errors in written expression in nouns.

Could it be easy to give me an example?

3) There is an elimination in student's errors in written expression in verbs.

Could it be easy to give me an example?

4) There is an elimination in student's errors in written expression in adjectives.

Could it be easy to give me an example? 
Appendix C. Worksheets for Nouns



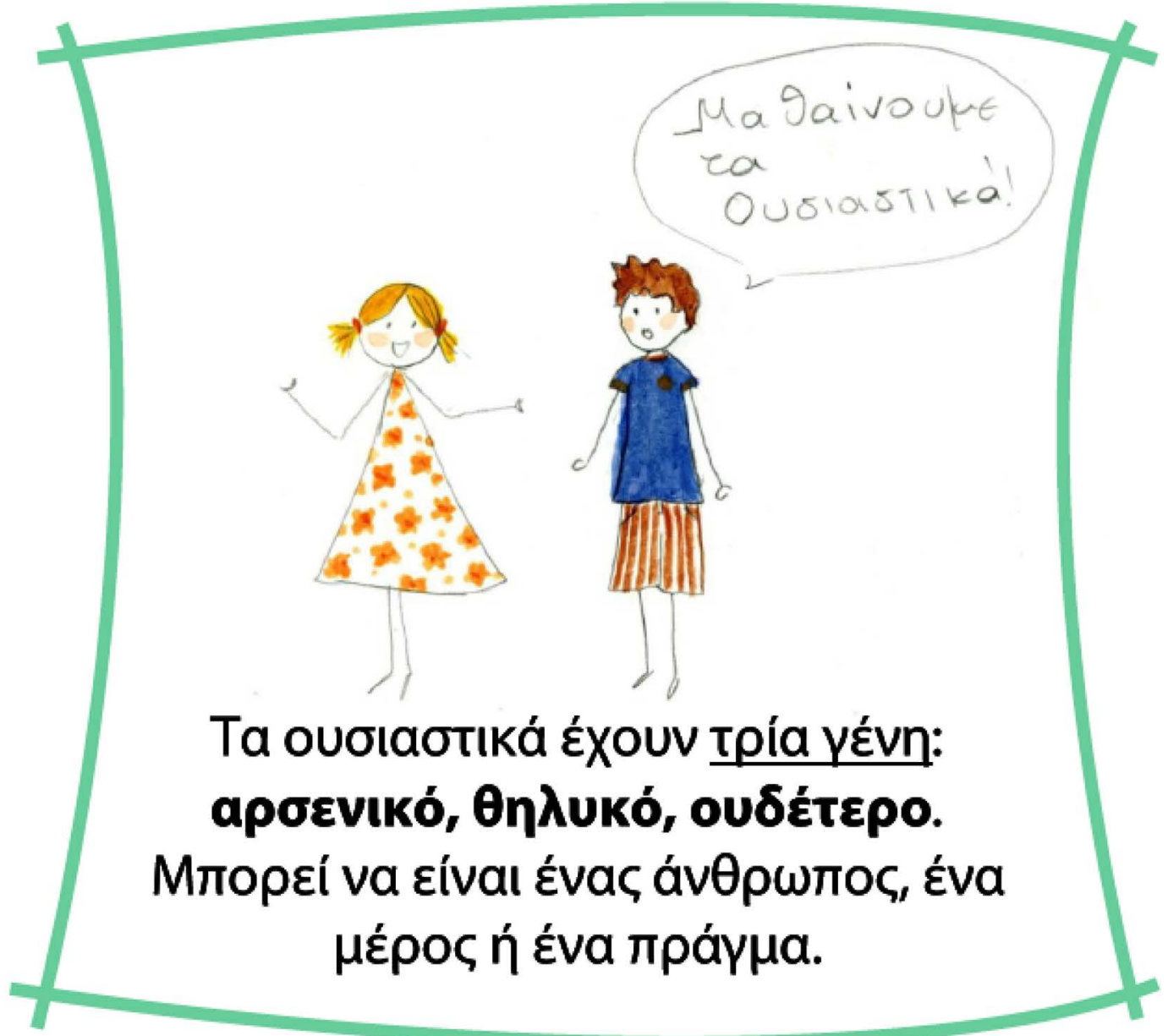




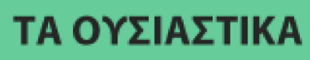

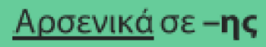

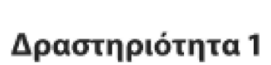

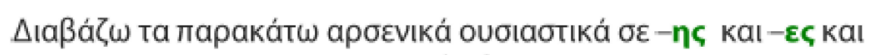



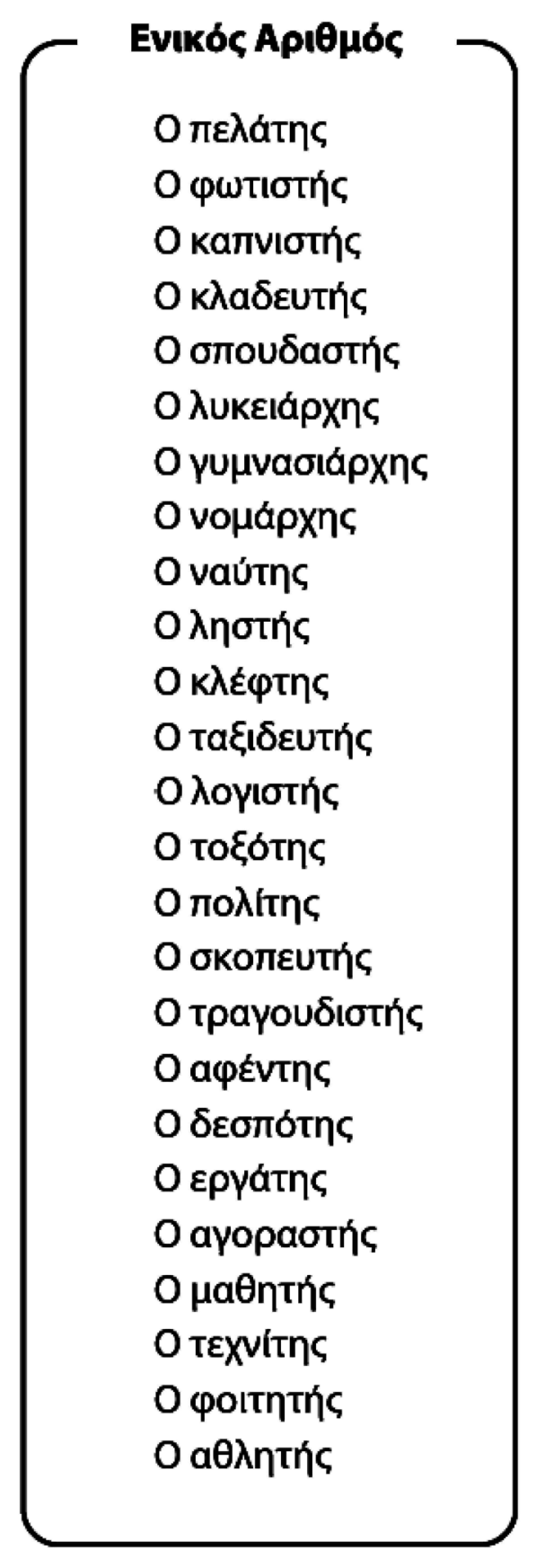

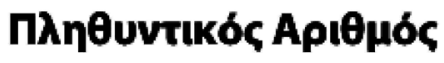





Oı katviбtéc

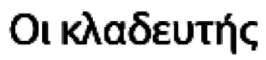



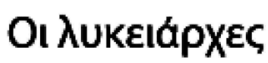

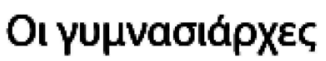

Oı vouápXec

Oı vaútec

Oı $\lambda$ пार́ৎ

ОІ $\mathrm{k} \lambda \varepsilon \varphi \varphi \varepsilon \varphi$

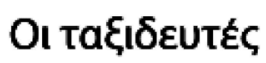



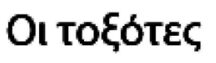

Оı по入ітеৎ

Oı бKопєUTદ́ৎ

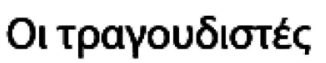

Oı a



Oı врүátec

Oı aүopaoté

Oı $\mu \mathrm{a} \theta \eta \bar{t} \varepsilon \bar{c}$

Oı тeXvites

Oı poItnTÉ

Oı $\alpha \theta \lambda \eta \tau \varepsilon \varsigma$ 
TA OVEIA

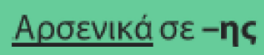

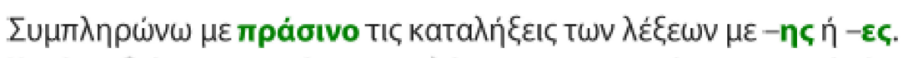

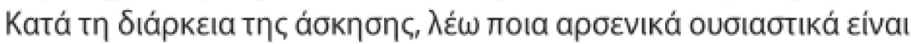

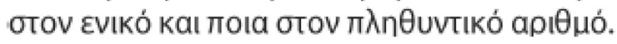

1. O

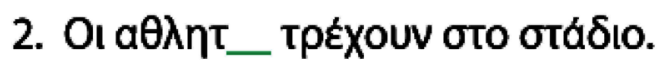

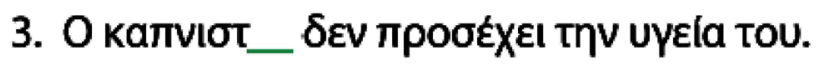

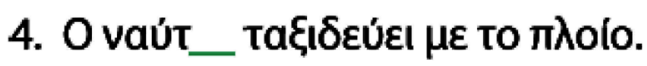



6. О

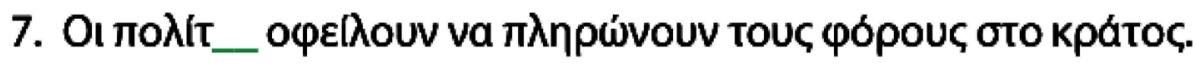

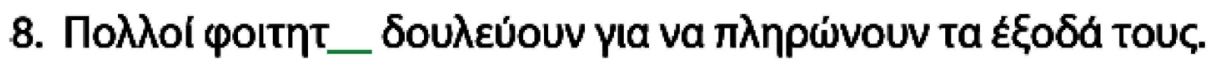

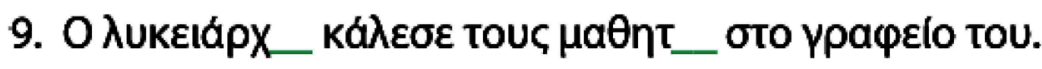

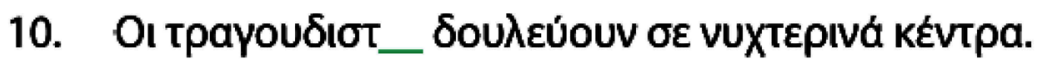

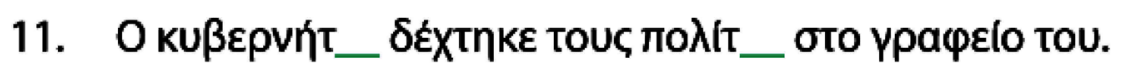

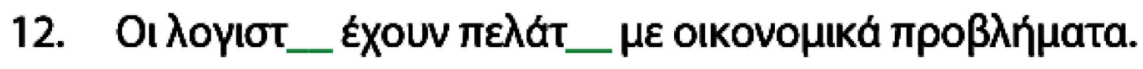




Appendix D. Worksheets for Adjectives

TA EПIOETA

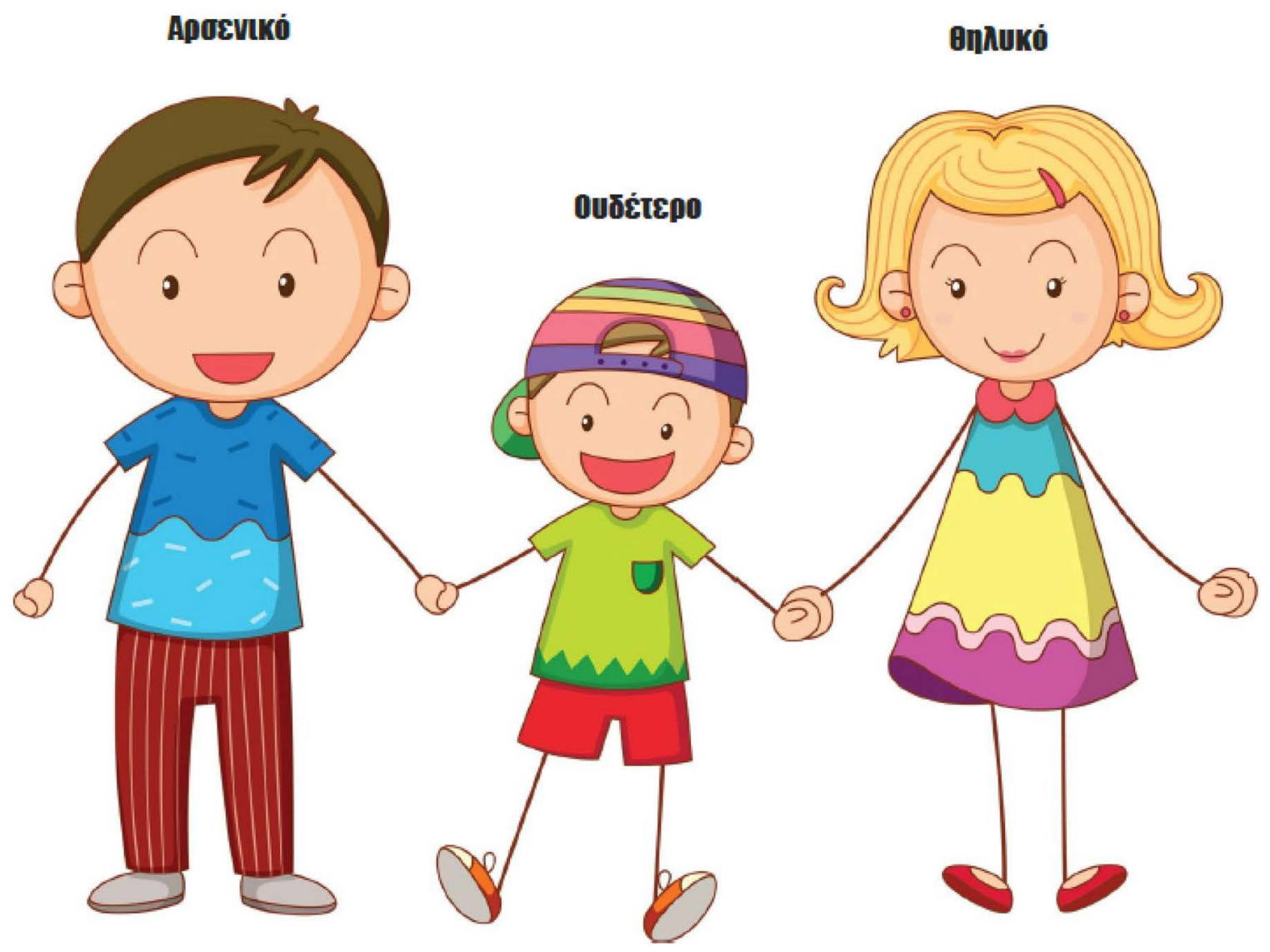

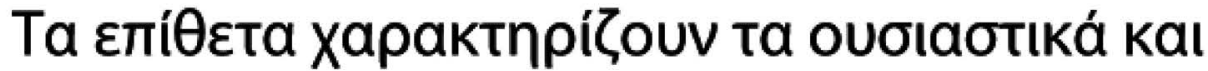

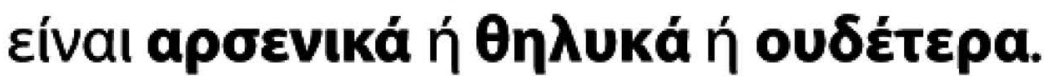


TA EПIOETA

-IVóc, -EIVóc, -UVOC,

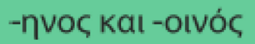

$\Delta$ paotipiótฑra 1

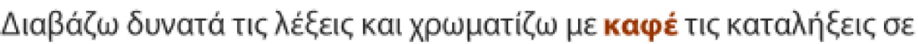
- Ivoc.

\begin{tabular}{|c|c|}
\hline накрıvóç & $\pi \varepsilon \delta ı$ ı́́ৎ \\
\hline Kovtivóç & 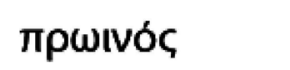 \\
\hline үıортіvós & 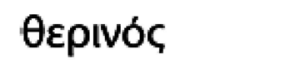 \\
\hline 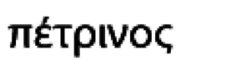 & каגокаıрıvóç \\
\hline кі́трıvoc & $\varphi \theta ı$ on \\
\hline KóKKIVOç & 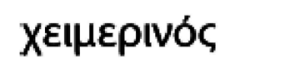 \\
\hline 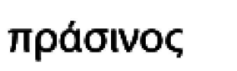 & 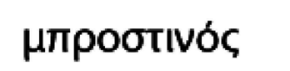 \\
\hline xáptivoç & 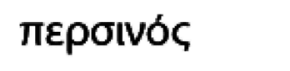 \\
\hline aépıvoc & छıvóç \\
\hline 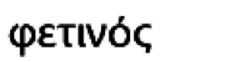 & ßuלavtivóç \\
\hline 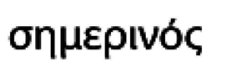 & ßopıvóç \\
\hline$\mu \varepsilon \lambda a x p ı v o ́ \varsigma$ & ßoóıvóç \\
\hline 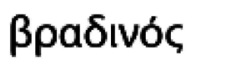 & yílivos \\
\hline 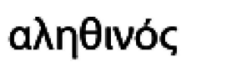 & 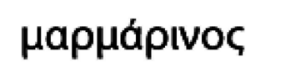 \\
\hline vuxtepıvóç & үuá入ivoç \\
\hline
\end{tabular}




\section{TA EПIOETA}

-IVóc, -Eıاvóc, -UVoç,

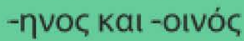

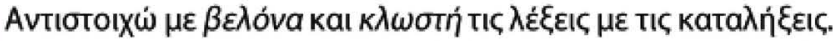

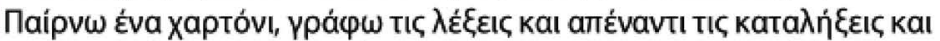

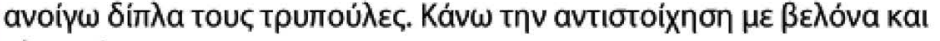
$\kappa \lambda \omega \sigma \eta \dot{n}$.
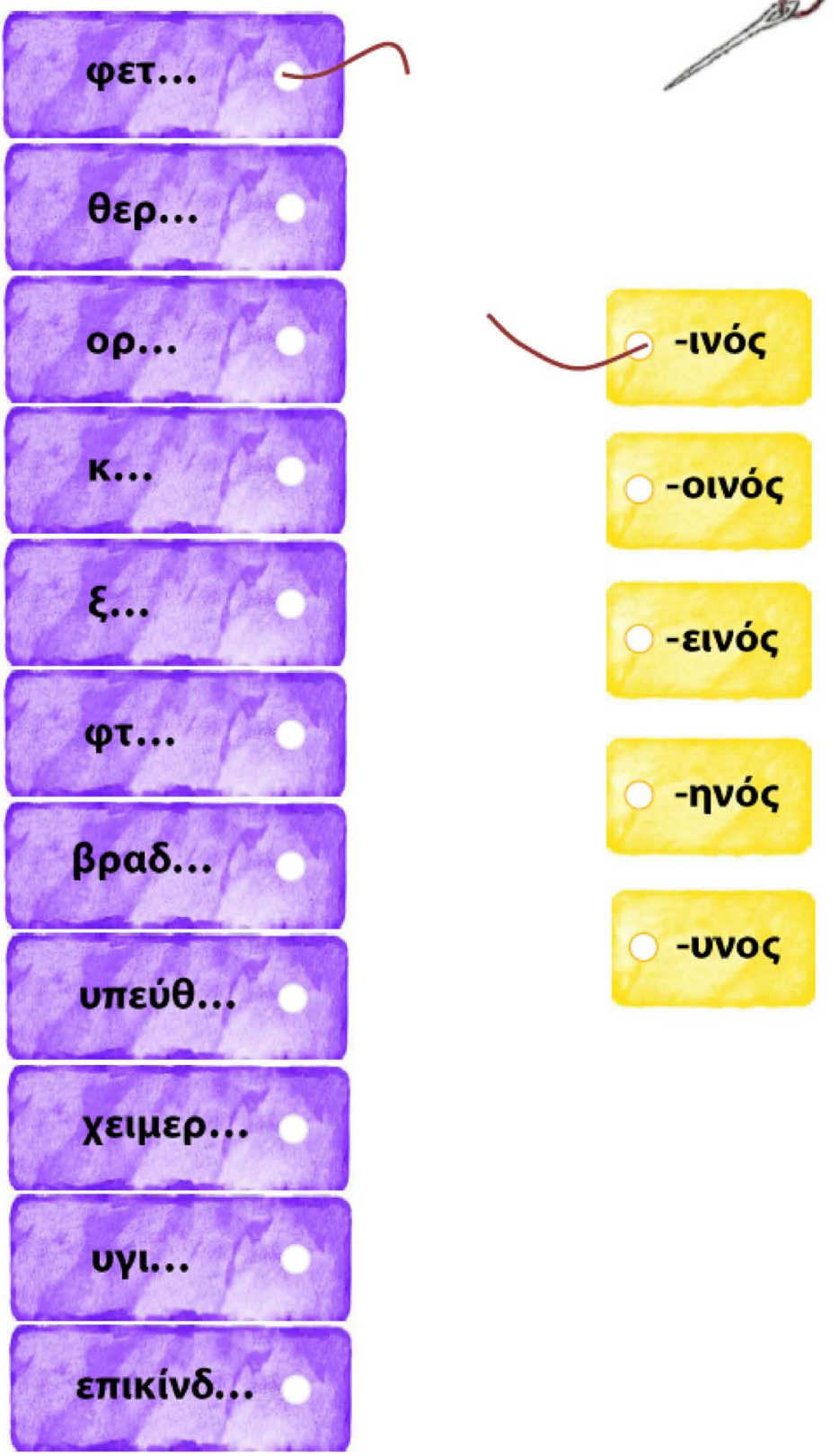
Appendix E. Worksheets for Verbs

TA PHMATA

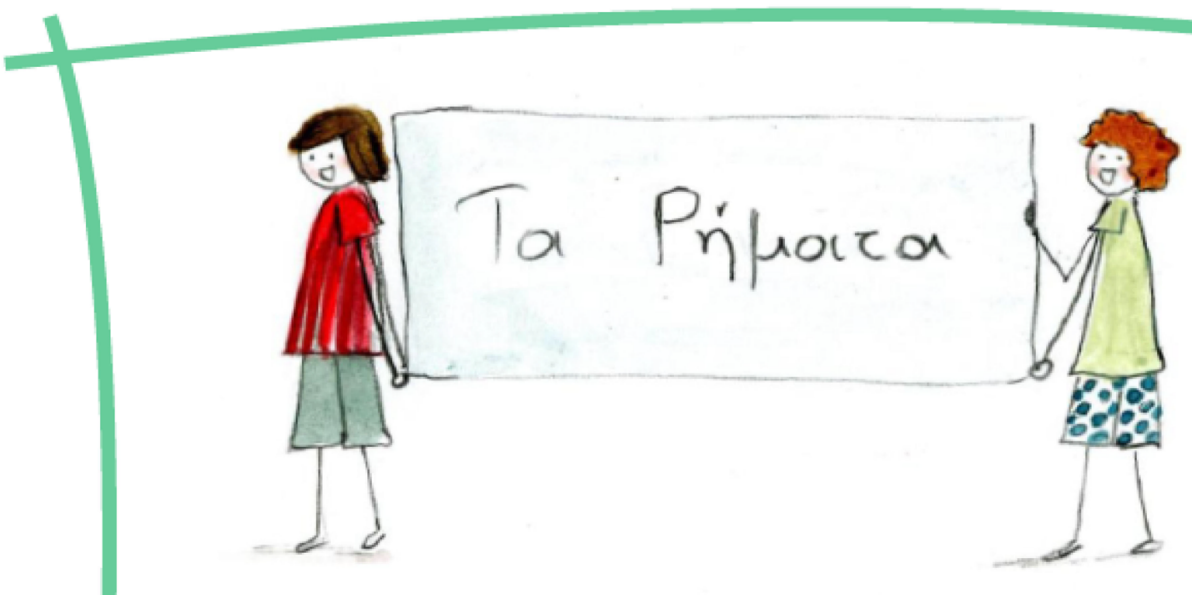

Ta pńpata on

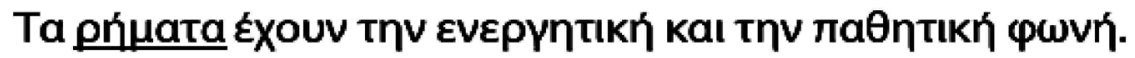

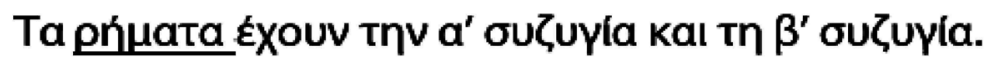

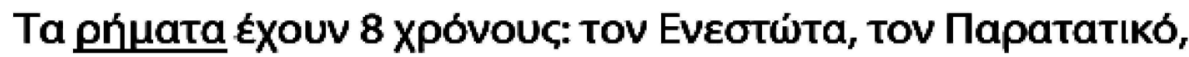

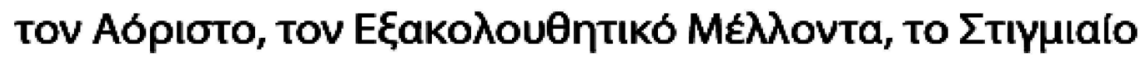

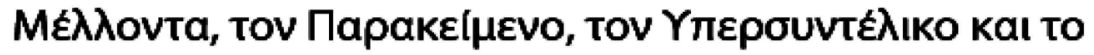

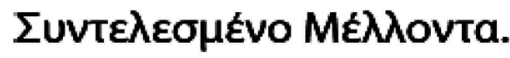

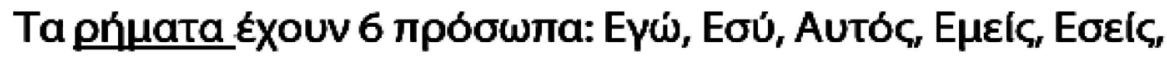
Autol

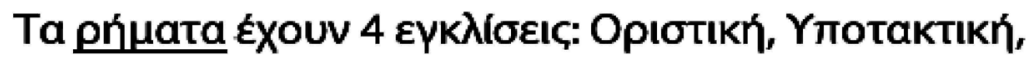
Атаре́

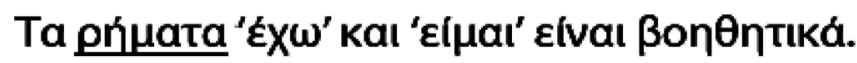

